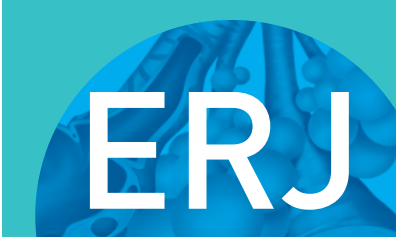

open research
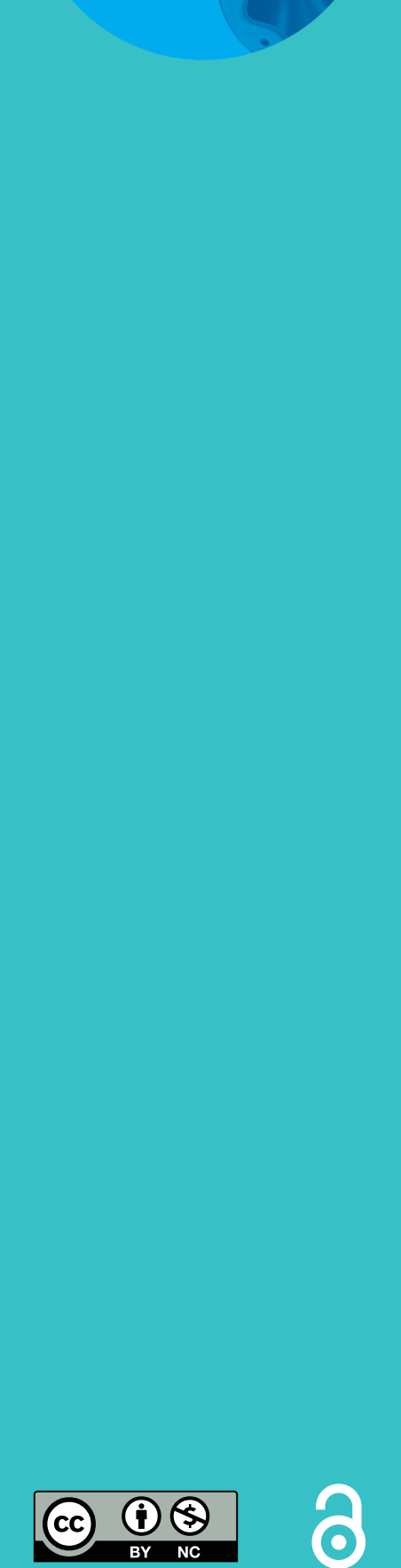

\title{
Revisiting early intervention in adult asthma
}

\author{
Tari Haahtela ${ }^{1}$, Olof Selroos ${ }^{2}$ and Paul M. O'Byrne ${ }^{3}$
}

Affiliations: ${ }^{1}$ Skin and Allergy Hospital, Helsinki University Central Hospital, Helsinki, Finland. ${ }^{2}$ Semeco AB, Ängelholm, Sweden and Helsinki University, Helsinki, Finland. ${ }^{3}$ Firestone Institute for Respiratory Health, St Joseph's Hospital and McMaster University, Hamilton, ON, Canada.

Correspondence: Tari Haahtela, Skin and Allergy Hospital, Helsinki University Central Hospital, PO B0X 160, FIN-00029 HUS, Finland. E-mail: tari.haahtelaahaahtela.fi

ABSTRACT The term "early intervention" with inhaled corticosteroids (ICS) in asthma is used in different ways, thereby causing confusion and misinterpretation of data. We propose that the term should be reserved for start of ICS therapy in patients with a diagnosis of asthma but within a short period of time after the first symptoms, not from the date of diagnosis. Prospective clinical studies suggest a time frame of 2 years for the term "early" from the onset of symptoms to starting anti-inflammatory treatment with ICS.

The current literature supports early intervention with ICS for all patients with asthma including patients with mild disease, who often have normal or near-normal lung function. This approach reduces symptoms rapidly and allows patients to achieve early asthma control. Later introduction of ICS therapy may not reduce effectiveness in terms of lung function but delays asthma control and exposes patients to unnecessary morbidity. Results of nationwide intervention programmes support the early use of ICS, as it significantly minimises the disease burden.

Acute asthma exacerbations are usually preceded by progressing symptoms and lung function decline over a period of 1-2 weeks. Treatment with an increased dose of ICS together with a rapid- and longacting inhaled $\beta_{2}$-agonist during this phase has reduced the risk of severe exacerbations.

@ERSpublications

ICS are the first-line therapy for diagnosed asthma and should be introduced early on the disease course http://ow.ly/Qxlef

Received: May 042015 | Accepted after revision: July 312015

Conflict of interest: Disclosures can be found alongside this article at openres.ersjournals.com

Copyright $\odot$ ERS 2015. This article is open access and distributed under the terms of the Creative Commons Attribution Non-Commercial Licence 4.0. 


\section{Introduction}

Asthma continues to be poorly understood in terms of its onset, severity, development and natural course over the patient's lifetime. The onset of asthma can be at any age but there are two main, distinctive clusters: in early childhood and in adults. Both populations seem to experience a pre-asthma stage characterised by intermittent symptoms but without the major lung function variability (or reversibility with inhaled $\beta_{2}$-agonists) required for the diagnosis of asthma.

In patients with diagnosed asthma, the course of disease may vary from no symptoms at all to life-threatening attacks. Asthma therapy was, at one time, aimed at symptomatic relief, using short-acting $\beta_{2}$-agonists and, in severe cases, systemic glucocorticoids. The concept of asthma control was developed with an insight into the inflammatory nature of the disease and the introduction of inhaled corticosteroids (ICS). A series of clinical studies from the beginning of the 1990s indicated that ICS, when initiated early after the onset of asthma symptoms, resulted in higher prebronchodilator lung function, fewer symptoms, less use of as-needed reliever medication and overall better asthma control than if introduced later [1-4]. These studies contributed to an increased early use of ICS in asthma of all severities.

This review evaluates the studies dealing with early intervention with ICS in which the duration of asthma has been well defined. We focus on studies in adult patients, as early intervention studies with ICS in infantile and childhood asthma have been recently reviewed [5].

We also discuss "early intervention" (or rapid intervention) in patients whose asthma control deteriorates and where effective therapies are proactively introduced or increased in order to stop a full exacerbation or attack.

\section{What is meant by early intervention?}

The literature reveals considerable variation both in the meaning and use of the term "early intervention". As asthma is a chronic inflammatory disease of the lower airways, ICS therapy is recommended as the first-line therapy in all patients with persistent disease [6]. This therapy is often incorrectly referred to as early intervention, as the disease may have lasted for several years before ICS therapy is instituted [7].

Some authors have used the term "early intervention" to mean initiation of therapy before a diagnosis of persistent asthma has been established, i.e. in children presenting with intermittent wheeze or in adults with asthma-like symptoms. These states should preferably be called "early childhood wheeze" or "pre-asthma", or "asthma-like airway inflammation", respectively, the latter when signs of airway inflammation such as sputum eosinophilia and/or increased levels of nitric oxide in exhaled air are present $[8,9]$. Others have described treatment with ICS at an early age (e.g. JónAsson et al. [10]). This type of treatment should be called "treatment of childhood asthma" and not mixed up with the term early intervention.

Even treatment of asthma patients presenting with mild symptoms has been referred to as early intervention studies, although the authors correctly report study results in patients with mild asthma [11-14]. Still others take it to mean early in terms of line of therapy, i.e. the use of ICS therapy when an alternative, but sometimes less effective, anti-inflammatory medication may work [15]. Often, these meanings are used interchangeably or without adequate definition and this has had a profound impact on how the results of interventional trials, in terms of the value of early intervention, are viewed [7].

Our original definition of early intervention meant treatment of patients who have relatively fresh symptoms (<2 years) regardless of the time-point of actual diagnosis $[1,2,4,16,17]$.

Altogether, the impetus to study early intervention was not only to gain rapid symptom control but also to explore whether asthma can be stopped from becoming a chronic and persistent disease with structural changes in the airways (remodelling) [18]. We also discuss early intervention in patients who show a symptom increase (e.g. with viral respiratory infections) and need more effective therapy to stop loss of control and, possibly, a full exacerbation.

\section{Early intervention studies}

The clinical studies in which the efficacy of early intervention with ICS has been compared with efficacy in patients with a longer duration of asthma or with placebo treatment are listed in table 1 . In these studies, the duration of asthma before starting therapy with ICS in the early intervention group has been $<2$ years.

HAAHTELA et al. [1] treated mild-to-moderate asthma patients with duration of symptoms <1 year in a randomised double-blind 2-year study comparing early treatment of budesonide $\left(1200 \mu \mathrm{g} \cdot \mathrm{day}^{-1}\right)$ with the early standard therapy at that time, regular inhaled terbutaline $\left(750 \mu \mathrm{g} \cdot \mathrm{day}^{-1}\right)$. Budesonide was found to be significantly better in terms of most measured variables. Thereafter, in a 1-year extension study, the terbutaline-treated patients were given identical budesonide treatment as that the budesonide group 
TABLE 1 Early Intervention trials of inhaled corticosteroid (ICS) therapy in patients with persistent asthma

\begin{tabular}{|c|c|c|c|c|c|c|c|}
\hline $\begin{array}{l}\text { First author or study } \\
\text { name [ref.]; study } \\
\text { design }\end{array}$ & Population & Subjects $n$ & ICS and dose & $\begin{array}{l}\text { Follow-up } \\
\text { period }\end{array}$ & Comparator(s) & Effect on lung function & Evidence of improved disease control \\
\hline $\begin{array}{l}\text { HAAHTELA [2]; } \\
\text { DB in one arm, } \\
\text { open in the other }\end{array}$ & $\begin{array}{l}\text { Mild-to-moderate asthma } \\
\text { Duration of symptoms } \\
<12 \text { months or } \\
<12 \text { months }+2 \text { years } \\
\text { Mean age } 37 \text { years }\end{array}$ & 74 & $\begin{array}{l}\text { Budesonide pMDI } \\
\quad+\text { spacer } \\
1200 \mu \mathrm{g} \cdot \text { day }^{-1}\end{array}$ & 1 year & $\begin{array}{l}\text { Budesonide } \\
\text { pMDI+spacer } \\
1200 \mu \mathrm{g} \cdot \text { day }{ }^{-1} \\
\text { with a 2-year delay }\end{array}$ & $\begin{array}{l}\text { Significant improvement in } \\
\text { prebronchodilator mPEF, } \\
\text { ePEF and FEV in both } \\
\text { groups but patients } \\
\text { treated early achieved } \\
\text { better lung function } \\
\text { Difference statistically } \\
\text { significant between early } \\
\text { and delayed therapy } \\
\text { (mPEF, p=0.006; ePEF, } \\
\text { p=0.004) }\end{array}$ & $\begin{array}{l}\text { Lower airway responsiveness in } \\
\text { patients treated without a } \\
2 \text {-year delay Difference } \\
\text { statistically significant ( } p=0.027 \text { ) }\end{array}$ \\
\hline $\begin{array}{l}\text { AGERTOFT [3]; } \\
\text { open, prospective }\end{array}$ & $\begin{array}{l}\text { Children with duration } \\
\text { of asthma } 0.5-10 \text { years, } \\
\text { mean } 3.7 \text { years }\end{array}$ & 278 & $\begin{array}{r}\text { Budesonide pMDI } \\
+ \text { spacer, } n=216\end{array}$ & $2-6$ years & No ICS therapy $(n=62)$ & $\begin{array}{l}\text { Significant negative } \\
\text { correlation between } \\
\text { duration of asthma and } \\
\text { annual improvement in } \\
\mathrm{FEV}(\mathrm{p}=0.01) \\
\text { Best improvement in } \\
\text { patients with asthma } \\
\text { duration <2 years }\end{array}$ & $\begin{array}{l}\text { Lower cumulative dose } \\
\text { of budesonide in patients } \\
\text { treated early }\end{array}$ \\
\hline $\begin{array}{l}\text { SELROos [4]; } \\
\text { open, retrospective }\end{array}$ & $\begin{array}{l}\text { Patients with asthma } \\
\text { symptoms of various } \\
\text { duration (<6 months, } \\
6-12 \text { months, } \\
1-2 \text { years, } 2-5 \text { years } \\
\text { and }>10 \text { years when } \\
\text { starting ICS therapy) }\end{array}$ & 105 & $\begin{array}{l}\text { Budesonide } \\
\text { varying doses }\end{array}$ & 2 years & No & $\begin{array}{l}\text { Significant negative } \\
\text { correlation between } \\
\text { duration of asthma } \\
\text { symptoms and maximum } \\
\text { improvement in } \\
\text { prebronchodilator } F E V_{1} \\
\text { (p=0.0012) and mPEF } \\
\text { (p=0.0006) } \\
\text { Best PEF improvement in } \\
\text { patients with asthma } \\
\text { symptom duration } \\
\text { < } 6 \text { months, }+110 \mathrm{~L} \cdot \mathrm{min}^{-1} \text {. } \\
\text { followed by patients } \\
\text { with symptom duration } \\
\text { of } 6-12 \mathrm{months}^{-1} \\
\left(+71 \mathrm{~L} \cdot \mathrm{min}^{-1}\right] \text { and } \\
1-2 \text { years }\left(+69 \mathrm{~L} \cdot \mathrm{min}^{-1} \text { ] }\right.\end{array}$ & \\
\hline SELRoos [17]; DB, R, P & $\begin{array}{l}\text { Mild-to-moderate asthma } \\
\text { Group A: symptoms } \\
<12 \text { months } \\
\text { Group B: symptoms } \\
>24 \text { months } \\
\text { Mean age }\end{array}$ & 81 & $\begin{array}{l}\text { Group A: budesonide } \\
100 \mu \mathrm{g} \text { twice daily } \\
\text { Group B: budesonide } \\
400 \mu \mathrm{g} \text { twice daily }\end{array}$ & 12 weeks & $\begin{array}{l}\text { Group A: budesonide } \\
100 \mu \text { twice daily } \\
\text { Group B: budesonide } \\
400 \mu \text { twice daily }\end{array}$ & $\begin{array}{l}\text { Group A: no difference } \\
\text { between doses in FEV } \\
\text { and } \mathrm{mPEF} \\
\text { Group B: higher dose } \\
\text { significantly better } \\
\text { in improving FEV } \\
\text { and } \mathrm{mPEF}\end{array}$ & $\begin{array}{l}\text { Group A: no difference between } \\
\text { doses in asthma symptoms, } \\
\text { and use of reliever medication } \\
\text { Group B: higher dose } \\
\text { significantly better in improving } \\
\text { symptoms, and reducing use of } \\
\text { reliever medication }\end{array}$ \\
\hline $\begin{array}{l}\text { SELRoos [16]; } \\
\text { open, prospective }\end{array}$ & $\begin{array}{l}\text { Mild-to-moderate } \\
\text { asthma } \\
\text { Mean age } 37-42 \text { years }\end{array}$ & 462 & $\begin{array}{l}\text { Budesonide varying } \\
\text { doses (duration } \\
\text { of asthma } \\
<2 \text { years) }\end{array}$ & 5 years & $\begin{array}{l}\text { Budesonide varying } \\
\text { doses (duration } \\
\text { of asthma } 2.5-18 \text { years) }\end{array}$ & $\begin{array}{l}\text { Difference in change in } \\
\text { mPEF and } \\
\text { prebronchodilator } \\
\text { FEV } 1 \text { statistically } \\
\text { significantly different } \\
\text { in favour of early } \\
\text { budesonide therapy } \\
\text { (p<0.001 for both) }\end{array}$ & $\begin{array}{l}\text { Lower maintenance dose of } \\
\text { budesonide Imean } 412 \mu \mathrm{g}, \\
\text { delayed therapy } 825 \mu \mathrm{g} ; \mathrm{p}<0.001 \text { ) } \\
\text { Less additional asthma medications } \\
\text { Statistically significantly fewer } \\
\text { patients used } \leq 3 \text { doses of } \\
\text { rescue medication } \\
\text { per day ( }<<0.001 \text { ) } \\
\text { Significantly fewer acute } \\
\text { exacerbations ( } p<0.001 \text { ) }\end{array}$ \\
\hline
\end{tabular}




\begin{tabular}{|c|c|c|c|c|c|c|c|}
\hline $\begin{array}{l}\text { First author or study } \\
\text { name [ref.]; study } \\
\text { design }\end{array}$ & Population & Subjects $n$ & ICS and dose & $\begin{array}{l}\text { Follow-up } \\
\text { period }\end{array}$ & Comparator(s) & Effect on lung function & Evidence of improved disease control \\
\hline & & & & & & & $\begin{array}{l}\text { Statistically significantly better } \\
\text { exercise tolerance }(p<0.001)\end{array}$ \\
\hline $\begin{array}{l}\text { OSteRMAN [19]; } \\
\text { DB, P }\end{array}$ & $\begin{array}{l}\text { Mild-to-moderate } \\
\text { asthma } \\
\text { Duration of asthma } \\
<12 \text { months } \\
\text { Mean age } 33-35 \text { years } \\
\text { No ICS therapy within } \\
3 \text { months }\end{array}$ & 68 & $\begin{array}{l}\text { Budesonide } \\
\quad 400 \mu \mathrm{g} \cdot \text { day }^{-1}\end{array}$ & $\begin{array}{c}1 \text { year } \\
\text { (6 months } \\
\text { follow-up) }\end{array}$ & Placebo & $\begin{array}{l}\text { Difference in change in } \\
\mathrm{mPEF} \text { statistically } \\
\text { significant in favour } \\
\text { of budesonide } \\
(\mathrm{p}=0.011)\end{array}$ & $\begin{array}{l}\text { Significantly lower airway } \\
\text { responsiveness }\left(P_{20}\right) \text { in } \\
\text { patients treated with } \\
\text { budesonide }(p=0.0003)\end{array}$ \\
\hline $\begin{array}{l}\text { START [20-23]; } \\
\text { DB, P, R }\end{array}$ & $\begin{array}{l}\text { Mild persistent } \\
\text { asthma <2 years } \\
\text { duration } \\
\text { Age 5-66 years } \\
\text { No previous regular } \\
\text { glucocorticosteroid } \\
\text { use }\end{array}$ & 7241 & $\begin{array}{l}\text { Budesonide } \\
400 \mu \mathrm{g} \cdot \text { day }^{-1} \\
\left(200 \mu \mathrm{g} \cdot \mathrm{day}^{-1}\right. \\
\text { in children } \\
<11 \text { years })\end{array}$ & 3 years & Placebo & $\begin{array}{l}\text { Budesonide improved } \\
\text { pre- and } \\
\text { postbronchodilator } \\
\text { FEV1 versus placebo }\end{array}$ & $\begin{array}{l}\text { Budesonide significantly } \\
\text { reduced the risk of a } \\
\text { severe asthma related event } \\
\text { (p<0.0001) and was associated } \\
\text { with more symptom-free } \\
\text { days }(p<0.0001)\end{array}$ \\
\hline $\begin{array}{l}\text { HEICA [24]; } \\
\text { DB, R, active } \\
\text { control, open }\end{array}$ & $\begin{array}{l}\text { Newly detected asthma } \\
\text { Age } 5-10 \text { years } \\
\text { No previous regular } \\
\text { glucocorticosteroid } \\
\text { use }\end{array}$ & 176 & $\begin{array}{l}\text { Budesonide } \\
\text { continuous } \\
\text { therapy ( } 400 \mu \mathrm{g} \\
\text { twice daily for } \\
1 \text { month, } 200 \mu \mathrm{g} \\
\text { twice daily months } \\
2-6,100 \mu \mathrm{g} \text { twice } \\
\text { daily months } \\
7-18 \text { ); or } \\
\text { budesonide as } \\
\text { above for months } \\
1-6, \text { thereafter } \\
\text { only as needed }\end{array}$ & 18 months & $\begin{array}{l}\text { DSCG } 10 \mathrm{mg} \\
\text { three times daily }\end{array}$ & $\begin{array}{l}\text { mPEF } \\
\text { No differences between } \\
\text { the } 3 \text { treatment groups } \\
\text { at } 6 \text { and } 18 \text { months } \\
\text { FEV }_{1} \text { : At } 6 \text { months } \\
\text { both budesonide } \\
\text { groups sign better } \\
\text { than DSCG; no } \\
\text { difference between } \\
\text { groups at } 18 \text { months }\end{array}$ & $\begin{array}{l}\text { During the first } 6 \text { months, } \\
\text { significantly fewer } \\
\text { exacerbations in the } \\
\text { budesonide groups compared } \\
\text { with DSCG; during months } \\
7-18 \text {, significantly fewer } \\
\text { exacerbations in the continuous } \\
\text { budesonide group compared } \\
\text { with intermittent budesonide } \\
\text { group and DSCG group } \\
\text { Median time to first exacerbation: } \\
\text { continuous budesonide, } \\
344 \text { days; intermittent } \\
\text { budesonide, } 268 \text { days; DSCG, } \\
78 \text { days ( }<0.001 \text { for both } \\
\text { budesonide groups compared } \\
\text { with DSCG) } \\
\text { Asthma-free days: at } 6 \text { months, } \\
\text { significant increase ( }<0.001 \text { ) } \\
\text { in both budesonide groups } \\
\text { compared with DSCG } \\
\text { As-needed use of reliever } \\
\text { medication: at } 6 \text { months, } \\
\text { significantly less use in } \\
\text { both budesonide groups } \\
\text { compared with DSCG ( } p=0.012 \text { ) }\end{array}$ \\
\hline
\end{tabular}

DB: double-blind; R; randomised; P: placebo-controlled; pMDI: pressurised metered-dose inhaler; DSCG: disodium cromoglycate; mPEF: morning peak expiratory flow; ePEF: evening peak expiratory flow; FEV1: forced expiratory flow in $1 \mathrm{~s}$; PD20: provocative dose causing a $20 \%$ fall in FEV1. 
received from the beginning [2]. This allowed a comparison of efficacy between early ICS (budesonide) therapy, within 1 year after the symptom start, with identical ICS therapy delayed for 2 years. Early intervention with ICS was significantly better at improving morning and evening peak expiratory flow (PEF) rates and bronchial hyperresponsiveness than delayed therapy.

Some of the differences between the groups were still present 10 years later, although not always significantly, as patients in the delayed-therapy group had received higher doses of ICS during the follow-up [25]. In addition, at the follow-up, the delayed-therapy group had more signs of active inflammation, as indicated by higher numbers of sputum neutrophils, and higher levels of myeloperoxidase and eosinophilic cationic protein than the early-therapy group.

Non-placebo controlled studies in adults have also reported the effect of early versus delayed therapy with ICS on airway function and bronchial responsiveness [4, 16, 17]. All studies have demonstrated a significant negative correlation between duration of asthma and response to ICS in terms of prebronchodilator airway function. The best improvements in prebronchodilator lung function have been described in patients with a duration of asthma symptoms $<6$ months, followed by patients with symptom durations of 6-24 months. Patients with a longer symptom history show a lesser but still clinically important response. Patients treated early have also had better exercise tolerance, less use of reliever medication, less need for other asthma medications and fewer acute exacerbations than patients starting ICS therapy when asthma duration has been $>2$ years [16]. The cumulative dose of ICS has also been found lower with early intervention $[16,26]$.

In a short-term (12 weeks), double-blind, placebo-controlled, randomised study, patients with symptoms for $<12$ months were compared with patients with a symptom duration $>24$ months (median 5.2 years, range 2-11 years) [17]. Patients in both groups were randomised to treatment with budesonide 100 or $400 \mu \mathrm{g}$ twice daily, or placebo. All four active treatment groups showed improved airway function and fewer symptoms compared with placebo. For patients with a short duration of asthma symptoms, the low dose was not inferior in effect to the high dose. However, in patients with a longer duration of symptoms, the higher dose was significantly better than the low dose in improving airway function and bronchial hyperresponsiveness.

Two studies have compared early intervention with inhaled budesonide with placebo in patients with mild-to-moderate [19] or mild asthma [20] and with duration of asthma of $<2$ years. The study by OSTERman et al. [19] included patients with a duration of asthma $<1$ year; some patients may have used inhaled steroids earlier, but not within the last 3 months prior to enrolment. Compared with placebo, treatment with ICS showed significant improvements in morning PEF and reduction of bronchial hyperresponsiveness.

The START study is by far the largest double-blind, placebo-controlled study in patients with newly detected (duration <2 years), mostly mild, persistent asthma not previously treated with ICS [20]. A total of 7221 patients received budesonide ( $400 \mu \mathrm{g}$ once daily, children younger than 11 years were given $200 \mu \mathrm{g}$ once daily) or placebo in addition to other asthma medications. The number of patients completing 3 years' randomised treatment was 5155. The risk (by Kaplan-Meier estimates) of having at least one exacerbation requiring hospital admission or emergency room treatment within 3 years was reduced from $6.4 \%$ in the placebo group to $3.7 \%$ in the budesonide group. At the end of the third treatment year, $24 \%$ of the patients in the placebo group received additional ICS medication, compared with $13 \%$ in the budesonide group. Budesonide-treated patients had more symptom-free days than those on placebo. The study also demonstrated significant improvements in both pre- and postbronchodilator forced expiratory volume in $1 \mathrm{~s}\left(\mathrm{FEV}_{1}\right)$ and a reduced mean decline from baseline for postbronchodilator FEV1 at 1 and 3 years [21].

After the 3-year double-blind period, all patients were given budesonide in an open fashion. In patients treated with placebo for 3 years, a catch-up was seen in all variables when they received budesonide, but they used more additional asthma medications compared with patients treated with budesonide from the beginning [22]. During the full 5-year period, patients with budesonide in the initial double-blind phase had a significantly lower cumulative risk (odds ratio 0.61) of having a severe asthma-related event than patients in the reference group. Postbronchodilator FEV1 decreased irrespective of randomised therapy during the double-blind phase by, on average, $2.2 \%$.

Recent data from GA ${ }^{2}$ LEN (Global Allergy and Asthma European Network) indicate that asthmatics have a steeper decline in postbronchodilator lung function with age compared with healthy controls [27]. Airway wall thickness was also measured in a study in 181 patients not earlier treated with ICS [28]. The patients were divided into five groups according to the duration of their asthma symptoms, which ranged from $<1$ to $>10$ years. High-resolution computed tomography images and postbronchodilator FEV1 were examined 
before and 1 year after treatment. Before treatment, airway wall thickness was increased relative to the duration of asthma. After ICS treatment, airway wall thickness decreased in patients with a duration of symptoms $<3$ years and a minor response was seen in patients with duration of symptoms from 3 to 5 years. However, there was no change in airway wall thickness in patients who had suffered asthma for $>5$ years. Thus, early ICS treatment may be critical to reverse airway wall thickening associated with asthma [28].

From the reviewed data, it is not possible to state that early intervention with ICS will alter the long-term functional course of asthma [29]. It seems, however, that long-term treatment with ICS slows down the decline in FEV 1 [30]. In a 10-year observational study in a general population, treatment with ICS was associated with a significantly less steep decline in FEV1 of $18 \mathrm{~mL} \cdot \mathrm{year}^{-1}$ compared with patients not treated with ICS. In addition, a post hoc analysis of the START study demonstrated that patients with severe asthma exacerbations had a greater decline in post-bronchodilator FEV1 when compared to those who did not have an exacerbation [23] and this effect was prevented by early ICS treatment. Thus, early ICS treatment may protect against FEV 1 decline.

In terms of asthma control, which has been the core message of Global Initiative for Asthma (GINA) asthma strategies since 2006, it is clear that early intervention with ICS therapy among patients with mild-to-moderate persistent asthma is most effective. But how intensive should therapy be and are high doses better than low doses? Should therapy be continuous or intermittent, and if intermittent, how long should the treatment periods be? Strategies using intermittent treatment have been suggested both for adults [31] and for children [24] but they need further support from larger controlled studies.

\section{Reducing or discontinuing ICS}

Gradual reduction and discontinuation of ICS in patients with chronic asthma (not newly detected) have usually resulted in a loss of asthma control, an increase in bronchial hyperresponsiveness and an accelerated rate of lung function decline [32-36]. In some studies, however, a 50\% reduction in ICS dose has been possible without loss of asthma control [37].

There are a few controlled studies addressing the question what happens when treatment with ICS is reduced or discontinued when treatment has been started early. In the study by HAAHTELA and coworkers $[1,2]$, the 2-year treatment dose, budesonide $1200 \mu \mathrm{g} \cdot$ day $^{-1}$ (pressurised metered-dose inhaler), was reduced for the third treatment year to $400 \mu \mathrm{g} \cdot \mathrm{day}^{-1}$ (Turbuhaler) or replaced with placebo. The lower ICS dose was sufficient to maintain good asthma control and prevent an increase in bronchial responsiveness, whereas two-thirds of the patients using placebo started to deteriorate: one-third soon after the dose reduction and the other third more towards the end of the placebo year. There were, however, patients who seemed to be in full remission, as they did not deteriorate at all during 1 year on placebo [2].

OSTERMAn et al. [19] followed their patients after the 1-year early-intervention treatment for another 6 months. During treatment with ICS airway function and bronchial responsiveness improved compared with placebo. During the follow-up, without ICS, the bronchial hyperresponsiveness increased by $50 \%$ but did not return back to the baseline.

\section{Early intervention with other anti-inflammatory drugs}

An alternative anti-inflammatory therapy for patients with mild-to-moderate asthma not tolerating or not willing to use ICS is a leukotriene receptor antagonist (LTRA). Meta-analyses have shown that LTRAs are consistently less effective than ICS in the treatment of asthma, both in children and adults [38, 39]. The addition of the LTRA montelukast to treatment with ICS has improved clinical end-points in patients with chronic asthma [40] and in another study the addition of montelukast to ICS resulted in the same degree of prevention from exacerbations as the addition of the long-acting $\beta_{2}$-agonist (LABA) salmeterol [41].

To the best of our knowledge, there are no studies in which the duration of asthma has been defined when treatment with a LTRA was initiated. Like in studies with ICS, the effect of LTRA also diminished if treatment was discontinued [42].

\section{Achieving early control}

In the real-life follow-up study [25], after a controlled 3-year trial [1, 2], it was found that 13 years after initiating ICS therapy in patients who had had asthma symptoms for $<1$ year, the majority of patients had well-controlled asthma and showed normal or near-normal lung function. Those patients treated with ICS from the outset had fewer symptoms, and used lower doses of ICS and less reliever $\beta_{2}$-agonists compared with those who received a $\beta_{2}$-agonist for the first 2 years although not all differences between the groups were statistically significant but pointing in the same direction. Moreover, the mean annual asthma drug costs and the number of hospital days per year were lower in the group receiving ICS from the outset. These figures are in line with the START study, where patients treated early with ICS had a lower risk of a 
severe asthma-related event than those in the reference group, and had improved asthma control and less additional use of asthma medications [22].

In the 13-year follow-up study, patients treated early with ICS also had fewer hospitalisations than those treated early with a $\beta_{2}$-agonist [25]. The hospitalised patients had a significantly lower lung function at the follow-up examination than those without hospitalisations, indicating, again, the value of early treatment with ICS. This is in agreement with the results of the START study where severe exacerbations were associated with a more rapid decline in lung function [23].

The early intervention with ICS was implemented nationwide in the 10-year asthma programme in Finland [43]. It focused on best clinical practice with early detection and treatment of inflammation, and the burden of asthma decreased considerably [26]. Most cost savings were achieved through reductions in emergency visits, hospitalisations, sickness allowances, disability pensions and loss of productivity. Similar experiences have been reported from Poland [44, 45], Brazil [46], Singapore [47] and Puerto Rico [48] despite quite different healthcare systems in these countries compared with Finland.

Well-controlled disease minimises the negative impact of asthma in daily life. This means fewer symptoms and less need for reliever medication, better airway function in the morning, and improvements in dimensions particularly relevant to children and adolescents, such as the ability to attend school or college, and to participate in physical activities and social development, and in those of greater importance to adults, such as the ability to work. The need to achieve disease control as soon as possible is recognised within current treatment guidelines, including those developed and updated in 2006-2014 by GINA.

\section{Preventing exacerbations}

Exacerbations of asthma vary in severity but the worst scenario is asthma death. Traditionally, exacerbations have been treated with increasing doses of bronchodilator drugs. However, gradually increasing symptoms and deterioration in airway function usually precede the attack for a period of 1-2 weeks [49]. This gradual deterioration in asthma control was described in detail in a study by TATTERSFIELD et al. [50]. They looked at change in PEF, symptoms and use of rescue medication during the 425 severe exacerbations that occurred during the 1-year, parallel-group study (FACET) in which low and high doses of budesonide, with and without formoterol, were compared in patients with moderate asthma. Exacerbations were characterised by a gradual fall in PEF over several days, followed by more rapid drop over 2-3 days; an increase in symptoms and rescue $\beta_{2}$-agonist use occurred in parallel, and both the severity and time course of the changes were similar in all treatment groups.

Worsening of asthma is not only a gradual narrowing in airway calibre combined with an increase in symptoms but primarily, and more importantly, an increase in the underlying airway inflammation. In patients with stable asthma requiring ICS at daily doses of $\geqslant 800 \mu \mathrm{g}$ beclomethasone or equivalents, mild exacerbations were induced by reducing the ICS treatment to $200 \mu \mathrm{g}$ budesonide per day [51]. The study demonstrated that an increase in the number of sputum eosinophils and an increase in exhaled nitric oxide, both being markers of airway inflammation, occurred before worsening of symptoms were reported. Therefore, maintaining asthma control during a phase of asthma deterioration and preventing exacerbations, especially at times of viral infections, requires an increase in anti-inflammatory medication in addition to more frequent use of reliever bronchodilators [52].

Prevention of severe exacerbations is attempted by increasing the daily treatment or adding new medications. Severe exacerbations are associated with a more rapid decline in lung function and this decline can be stopped by the effective use of ICS [23]. The therapeutic strategies available have been recently reviewed [53]. These include ICS, the combination of ICS and the inhaled LABA formoterol, LTRA, and anti-IgE and anti-interleukin-5 monoclonal antibodies.

A successful strategy to avoid severe exacerbations was demonstrated in the 1-year FACET study [49]. The study evaluated asthma patients already taking moderate doses of ICS but with poorly controlled asthma. During a run-in period, all patients were treated with budesonide $1600 \mu \mathrm{g} \cdot \mathrm{day}^{-1}$ in an attempt to achieve good asthma control. They were then randomised to a low $\left(200 \mu \mathrm{g} \cdot\right.$ day $\left.^{-1}\right)$ or moderate dose $\left(800 \mu \mathrm{g} \cdot \mathrm{day}^{-1}\right)$ of budesonide with or without concomitant treatment with formoterol. Significantly fewer severe exacerbations were seen in the higher ICS dose group compared with the low-dose ICS group. The addition of formoterol on both dose levels of budesonide significantly further reduced the risk of severe exacerbations on both dose levels of ICS.

Similarly, in patients with mild persistent asthma who were not sufficiently well controlled on an ICS alone, the addition of formoterol to a low-dose budesonide significantly reduced the rate of asthma exacerbations [12].

In the real-world setting, exacerbation rates for patients with chronic, severe asthma may not be significantly affected, even with continuous, high-intensity treatment [54]. 
Increasing the dose of ICS

Physicians often recommended doubling the dose of ICS but controlled clinical studies indicate that this increase in ICS dose is not sufficient to prevent the exacerbation [55-57]. However, quadrupling the dose of ICS reduced the risk of developing an acute exacerbation, at least exacerbations requiring treatment with oral corticosteroids [58].

As early as the mid-1990s, a randomised study in Finland showed that guided self-management with patients' own adjustment of anti-inflammatory medication based on symptoms and home PEF measurements halved exacerbations and other asthma events during the study year compared with traditional therapy [59]. In these patients, doubling the ICS dose proactively was usually sufficient to prevent exacerbations. The guided self-management also resulted in reduced asthma care costs [60]. A systematic review of 36 trials found guided self-management of asthma in adults to be clearly advantageous compared with usual care, significantly improving patients' health [61].

Introducing the ICS/LABA combination

Based on the aforementioned "ICS-quadrupling dose approach", a treatment strategy was developed called "adjustable maintenance therapy with budesonide/formoterol". Patients with moderate asthma were treated with a low dose of budesonide/formoterol. If symptoms worsened, the dose of budesonide/formoterol was quadrupled for 7 days and, thereafter, reduced to the previous maintenance dose. Compared with twice as high fixed-dose maintenance therapy without adjustments, the adjustable regimen resulted in a reduced risk of exacerbations [62-66].

The results of the adjustable maintenance therapy with budesonide/formoterol indicated that additional early anti-inflammatory treatment together with increasing doses of a rapid-acting bronchodilator would be beneficial. It appeared that in early exacerbations, ICS should be added to the bronchodilator given for relief of symptoms. This hypothesis could be tested with the budesonide/formoterol combination inhaler as formoterol, in addition to being long-acting, also has a rapid onset of action [67, 68]. Formoterol also exhibited a dose response in which increasing doses provided additional bronchodilating effects [68, 69]. The hypothesis was evaluated in a series of large clinical studies. These studies consistently demonstrated that the combination of budesonide/formoterol for both maintenance and as-needed therapy reduced severe exacerbations, reduced the need for reliever medication and improved lung function compared with either budesonide/formoterol or a four-fold higher dose of budesonide for maintenance therapy [70-73]. The results of most these studies have recently been reviewed and summarised[52, 74]. Similar results have also been described with beclomethasone dipropionate and formoterol combination inhalers [75]. Nevertheless, a recent real-world study concluded that when applied to a broad primary care population, anti-inflammatory therapy using increased doses of ICS is as effective as adding LABAs, as measured by outcomes important to both patients and providers [76].

It appears that early use of budesonide/formoterol as needed instead of a short-acting bronchodilator together with maintenance therapy prevents the development of acute severe exacerbations. This therapy is considered by some to be the preferred option for patients in steps 2-4 of asthma guidelines [77]. The overall principle, however, should be that at times of deterioration, the treatments should be sufficiently increased in order to avoid exacerbations. When control is achieved again, the doses should be gradually reduced to an individual maintenance level. A risk score for asthma exacerbations has been developed and this might guide the management of asthma patients [78].

\section{Conclusions}

Once a decision has been reached to intervene with pharmacotherapy in patients with asthma, ICS should be considered as first-line therapy as they offer the most effective asthma control, reduce the risk of exacerbations and minimise the burden of the disease. Several studies have shown that early intervention with ICS in asthma, i.e. studies in which ICS therapy has been initiated when patients have had asthma symptoms for $<2$ years, offers effective asthma control. It reduces symptoms, improves prebronchodilator airway function, bronchial hyperresponsiveness and airway inflammation, reduces asthma exacerbations, and improves quality of life compared with a later introduction of ICS. When delivered continuously, ICS also appears to slow down the decline in lung function.

It is very difficult (and expensive) to study how effective early ICS treatment is in slowing down the lung function decline over the years in those with a more severe and persistent disease. Some researchers find this essential, if ICS is claimed to change the "natural course" of the disease. This discussion seems to be somewhat academic, if a patient would either live or die depending on whether the treatment is effective or not. Earlier and more effective anti-inflammatory management of asthma has gained remarkable results. In 1990, in Europe, 6441 patients died because of asthma, versus 1164 in 2012, i.e. 80\% decrease [79]. In Finland, the number of hospital days decreased by $67 \%$ and emergency visits by $46 \%$ during the years 
2000-2013. Asthma mortality in patients under the age of 60 years has been almost abolished. In 2001, $10 \%$ of the Finnish asthmatics on long-term maintenance treatment reported their asthma as severe compared to $4 \% 10$ years later [80]. There is no question at the moment that the favourable development is due to improved anti-inflammatory therapy.

Improved detection of lower airway inflammation in patients with symptoms suggestive asthma but with normal lung function may provide rationale for ICS treatment periods even earlier in the course of disease [81]. However, there are no studies to show that this strategy would stop asthma development.

The key issue to reduce the public health burden of asthma is to stop the increasing symptoms and exacerbations as early as possible. That can be achieved by promoting patient education and guided self-management by which patients start or increase their medication proactively according to professional advice by a trained nurse or a doctor. It seems that treatment of developing exacerbations with early administration of an ICS/LABA combination provides better prevention from severe exacerbations than higher doses of ICS with a short-acting bronchodilator used as needed.

\section{References}

1 Haahtela $T$, Järvinen $M$, Kava $T$, et al. Comparison of a $\beta_{2}$-agonist, terbutaline, with an inhaled corticosteroid, budesonide, in newly detected asthma. N Engl J Med 1991; 325: 388-392.

2 Haahtela T, Järvinen M, Kava T, et al. Effect of reducing or discontinuing inhaled budesonide in patients with mild asthma. N Engl J Med 1994; 331: 700-705.

3 Agertoft L, Pedersen S. Effects of long-term treatment with an inhaled corticosteroid on growth and pulmonary function in asthmatic children. Respir Med 1994; 88: 373-381.

4 Selroos $\mathrm{O}$, Pietinalho A, Löfroos AB, et al. Effect of early vs late intervention with inhaled corticosteroids in asthma. Chest 1995; 108: 1228-1234.

5 Yoshihara S. Early intervention for infantile and childhood asthma. Exp Rev Clin Immunol 2010; 6: 247-255.

6 Reddel HK, Bateman ED, Becker A, et al. A summary of the new GINA strategy: a roadmap to asthma control. Eur Respir J 2015 [In press DOI: 10.1183/13993003.00853-2015].

7 Pedersen S. Early pharmacological intervention in mild pediatric asthma - background and definitions. Pediatr Allergy Immunol 2006; 17: Suppl. 17, 5-6.

8 Rytilä $\mathrm{P}$, Metso T, Heikkinen K, et al. Airway inflammation in patients with symptoms suggesting asthma but with normal lung function. Eur Respir J 2000; 16: 824-830.

9 Haahtela T. Eosinophilic bronchial inflammation. Early intervention with inhaled corticosteroids. Allergy Clin Immunol 2004; 16: 4-8.

10 Jónasson G, Carlsen KH, Blomqvist P. Clinical efficacy of low-dose inhaled budesonide once or twice daily in children with mild asthma not previously treated with steroids. Eur Respir J 1998; 12: 1099-1104.

11 Childhood Asthma Management Program Research Group. The Childhood Asthma Management Research Group. Long-term effects of budesonide or nedocromil in children with asthma. N Engl J Med 2000; 343: 1054-1063.

12 O’Byrne PM, Barnes PJ, Rodrigues-Roisin R, et al. Low dose inhaled budesonide and formoterol in mild persistent asthma. The OPTIMA randomized trial. Am J Respir Crit Care Med 2001; 164: 1392-1397.

13 Arets HGM, Kamps AWA, Brackel HJL, et al. Children with mild asthma: do they benefit from inhaled corticosteroids? Eur Respir J 2002; 20: 1470-1475.

14 Garcia Garcia ML, Wahn U, Gilles L, et al. Montelukast, compared with fluticasone, for control of asthma among 6- to 14-year-old patients with mild asthma: the MOSAIC study. Pediatrics 2005; 116: 360-369.

15 Kumar V, Ramseh P, Lodha R, et al. Montelukast vs. inhaled low-dose budesonide as monotherapy in the treatment of mild persistent asthma: a randomized double blind controlled trial. J Tropical Pediatr 2007; 53: 325-330.

16 Selroos $\mathrm{O}$, Löfroos $\mathrm{AB}$, Pietinalho $\mathrm{A}$, et al. Asthma control and steroid doses 5 years after early or delayed introduction of inhaled corticosteroids in asthma: a real-life study. Respir Med 2004; 98: 254-262.

17 Selroos O. Effect of disease duration on dose-response of inhaled budesonide in asthma. Respir Med 2008; 102: $1065-1072$.

18 Bousquet J, Chanez P, Lacoste JY, et al. Asthma: a disease remodeling the airways. Allergy 1992; 47: 3-11.

19 Osterman K, Carlholm M, Ekelund J, et al. Effect of 1year daily treatment with $400 \mu \mathrm{g}$ budesonide (Pulmicort Turbuhaler) in newly diagnosed asthmatics. Eur Respir J 1997; 10: 2210-2215.

20 Pauwels RA, Pedersen S, Busse WW, et al. Early intervention with budesonide in mild persistent asthma: a randomised, double-blind trial. Lancet 2003; 361: 1071-1076.

21 O'Byrne PM, Pedersen S, Busse WW, et al. Effects of early intervention with inhaled budesonide on lung function in newly diagnosed asthma. Chest 2006; 129: 1478-1485.

22 Busse WW, Pedersen S, Pauwels RA, et al. START study 5-year follow-up: effectiveness of early intervention with budesonide in mild persistent asthma. J Allergy Clin Immunol 2008; 121: 1167-1174.

23 O’Byrne PM, Pedersen S, Lamm CJ, et al. Severe exacerbations and decline in lung function in asthma. Am J Respir Crit Care Med 2009; 179: 19-24.

24 Turpeinen M, Nikander K, Pelkonen AS, et al. Daily versus as-needed inhaled corticosteroid for mild persistent asthma. Arch Dis Child 2008; 93: 654-659.

25 Haahtela T, Tamminen K, Malmberg P, et al. Follow-up results 10 years after early intervention with budesonide or terbutaline in mild persistent asthma. J Allergy Clin Immunol 2009; 124: 1180-1185.

26 Haahtela T, Tuomisto LE, Pietinalho A, et al. A 10-year asthma programme in Finland: major change for the better. Thorax 2006; 61: 663-670.

27 Obaseki D, Potts J, Joos G, et al. The relation of airway obstruction to asthma, chronic rhinosinusitis and age: results from a population survey of adults. Allergy 2014; 69: 1205-1214.

28 Kurashima K, Kanauchi T, Hoshi T, et al. Effect of early versus late intervention with inhaled corticosteroids on airway wall thickness in patients with asthma. Respirology 2008; 13: 1008-1013. 
29 Haahtela T. Lung function decline in asthma and early intervention with inhaled corticosteroids. Chest 2006; 129: 1405-1406.

30 Lange P, Scharling H, Suppli Ulrik C. Inhaled corticosteroids and decline of lung function in community residents with asthma. Thorax 2006; 61: 100-104.

31 Boushey HA, Sorkness CA, King TS, et al. Daily versus as-needed corticosteroids for mild persistent asthma. N Eng J Med 2005; 352: 1519-1528.

32 van Essen-Zandvliet EE, Hughes MD, Waalkens HJ, et al. Remission of childhood asthma after long-term treatment with an inhaled corticosteroid (budesonide): can it be achieved? Dutch CNSLD study group. Eur Respir J 1994; 7: 63-68.

33 Waalkens HJ, van Essen Zandvliet EE, Hughes MD, et al. Cessation of long-term treatment with inhaled corticosteroid (budesonide) in children with asthma results in deterioration. Am Rev Respir Dis 1993; 148: $1252-1257$.

34 Simons FER. A comparison of beclomethasone, salmeterol, and placebo in children with asthma. New Engl J Med 1997; 337: 1659-1665.

35 Gershman NH, Wong HH, Liu JT, et al. Low- and high-dose fluticasone propionate in asthma; effects during and after treatment. Eur Respir J 2000; 15: 11-18.

36 Leuppi JD, Salome CM, Jenkins CR, et al. Predictive markers of asthma exacerbations during stepwise dose reduction of inhaled corticosteroids. Am J Respir Crit Care Med 2001; 163: 406-412.

37 Hawkins G, McMahon AD, Twaddle S, et al. Stepping down inhaled corticosteroids in asthma: randomised controlled trial. Brit Med J 2003; 326: 1115.

38 Ducharme FM. Inhaled corticosteroids versus leukotriene antagonists as first-line therapy for asthma: a systematic review of current evidence. Treat Respir Med 2004; 3: 399-405.

39 Castro-Rodriguez JA, Rodrigo GJ. The role of inhaled corticosteroids and montelukast in children with mild-moderate asthma: results of a systematic review with meta-analysis. Arch Dis Child 2010; 95: 365-370.

40 Vaquerizo MJ, Casan P, Castillo J, et al. Effect of montelukast added to inhaled budesonide on control of mild to moderate asthma. Thorax 2003; 58: 204-210.

41 Bjermer L, Bisgaard H, Bousquet J, et al. Montelukast and fluticasone compared with salmeterol and fluticasone in protecting against asthma exacerbation in adults: one year, double blind, randomized, comparative trial. Brit Med J 2003; 327: 891.

42 Montuschi P, Mondino C, Koch P, et al. Effects of montelukast treatment and withdrawal on fractional exhaled nitric oxide and lung function in children with asthma. Chest 2007; 132: 1876-1681.

43 Haahtela T, Klaukka T, Koskela K, et al. Asthma programme in Finland: a community problem needs community solutions. Thorax 2001; 56: 806-814.

44 Stelmach W, Majak P, Jerzynska J, et al. Early effects of asthma prevention program on asthma diagnosis and hospitalization in urban population of Poland. Allergy 2005; 60: 606-610.

45 Kupczyk M, Haahtela T, Cruz AA, et al. Reduction of asthma burden is possible through National Asthma Plans. Allergy 2010; 65: 415-419.

46 Cruz AA, Souza-Machado A, Franco R, et al. The impact of a program for control of asthma in a low-income setting. WHO J 2010; 3: 167-174.

47 Chong NP, Tan NC, Lim TK. Impact of the Singapore National Asthma Program (SNAP) on preventor-reliever prescription ratio in polyclinics. Ann Acad Med Singapore 2008; 37: 114-117.

48 Soto-Martínez M, Avila L, Soto N, et al. Trends in hospitalizations and mortality from asthma in Costa Rica over a 12- to 15-year period. J Allergy Clin Immunol Pract 2014; 2: 85-90.

49 Pauwels RA, Löfdahl CG, Postma DS, et al. Effect of inhaled formoterol and budesonide on exacerbations of asthma. Formoterol and Corticosteroid Establishing Therapy (FACET) International Study Group. N Engl J Med 1997; 337: 1405-1411.

50 Tattersfield AE, Postma DS, Barnes PJ, et al. Exacerbations of asthma: a descriptive study of 425 severe exacerbations. Am J Respir Crit Care Med 1999; 160: 594-599.

51 Jatakanon A, Lim S, Barnes PJ. Changes in sputum eosinophils predict loss of asthma control. Am J Respir Crit Care Med 2000; 161: 64-72.

52 Selroos O. A smarter way to manage asthma with a combination of a long-acting $\beta_{2}$-agonist and inhaled corticosteroid. Ther Clin Risk Management 2007; 3: 349-359.

53 O'Byrne PM. Therapeutic strategies to reduce asthma exacerbations. J Allergy Clin Immunol 2011; 128: 257-263.

54 Schatz M, Meckley LM, Kim M, et al. Asthma exacerbation rates in adults are unchanged over a 5-year period despite high-intensity therapy. J Allergy Clin Immunol Pract 2014; 2: 570-574.

55 Harrison TW, Oborne J, Newton S, et al. Doubling the dose of inhaled corticosteroid to prevent asthma exacerbations: randomised controlled trial. Lancet 2004; 363: 271-275.

56 Fitzgerald JM, Becker A, Sears MR, et al. Doubling the dose of budesonide versus maintenance treatment in asthma exacerbations. Thorax 2004; 59: 550-556.

57 Quon BS, Fitzgerald JM, Lemière C, et al. Increased versus stable doses of inhaled corticosteroids for exacerbations of chronic asthma in adults and children. Cochrane Database Syst Rev 2010; CD007524.

58 Oborne J, Mortimer K, Hubbard RB, et al. Quadrupling the dose of inhaled corticosteroid to prevent asthma exacerbations: a randomized, double blind, placebo controlled, parallel group, clinical trial. Am J Respir Crit Care Med 2009; 180: 598-602.

59 Lahdensuo A, Haahtela T, Herrala J, et al. Randomised comparison of guided self management and traditional treatment of asthma over one year. Brit Med J 1996; 312: 748-752.

60 Lahdensuo A, Haahtela T, Herrala J, et al. Randomised comparison of cost effectiveness of guided self management and traditional treatment of asthma in Finland. Brit Med J 1998; 316: 1138-1139.

61 Gibson PG, Powell PG, Wilson A, et al. Self-management education and regular practitioner review for adults with asthma. Cochrane Database Syst Rev 2002; CD001117.

62 Ställberg B, Olsson P, Jörgensen LA, et al. Budesonide/formoterol adjustable maintenance dosing reduces asthma exacerbations versus fixed dosing. Int J Clin Pract 2003; 57: 656-661. 
63 FitzGerald JM, Sears MR, Boulet LP, et al. Adjustable maintenance dosing with budesonide/formoterol reduces asthma exacerbations compared with traditional fixed dosing: a five-month multicentre Canadian study. Can Respir J 2003; 10: 427-434.

64 Aalbers R, Backer V, Kava TT, et al. Adjustable maintenance dosing with budesonide/formoterol compared with fixed-dose salmeterol-fluticasone in moderate to severe asthma. Curr Med Res Opin 2004; 20: 225-240.

65 Buhl R, Kardos P, Richter K, et al. The effect of adjustable dosing with budesonide/formoterol on health-related quality of life and asthma control compared with fixed dosing. Curr Med Opin 2004; 20: 1209-1229.

66 Ind PW, Haughney J, Price D, et al. Adjustable and fixed dosing with budesonide/formoterol via a single inhaler in asthma patients: the ASSURE study. Respir Med 2004; 98: 464-475.

67 Palmqvist M, Persson G, Lazer L, et al. Inhaled dry-powder formoterol and salmeterol in asthmatic patients: onset of action, duration of effect and potency. Eur Respir J 1997; 10: 2484-2489.

68 Selroos O. The pharmacological and clinical properties of Oxis $^{\circ}$ (formoterol) Turbuhaler ${ }^{\circ}$. Allergy 1998; 53: 14-19.

69 Ringdal N, Derom E, Wåhlin-Boll E, et al. Onset and duration of action of single doses of formoterol inhaled via Turbuhaler'. Respir Med 1998; 92: 1017-1021.

70 O'Byrne PM, Bisgaard H, Godard PP, et al. Budesonide/formoterol combination therapy as both maintenance and reliever medication in asthma. Am J Respir Crit Care Med 2005; 171: 129-136.

71 Rabe KF, Atienza T, Magyar P, et al. Effect of budesonide in combination with formoterol for reliever therapy in asthma exacerbations: a randomised controlled, double-blind study. Lancet 2006; 368: 744-753.

72 Bousquet J, Boulet LP, Peters MJ, et al. Budesonide/formoterol for maintenance and relief in uncontrolled asthma vs. high-dose salmeterol/fluticasone. Respir Med 2007; 101: 2437-2446.

73 Papi A, Paggiaro PL, Nicolini G, et al. Beclomethasone/formoterol versus budesonide/formoterol combination therapy in asthma. Eur Respir J 2007; 29: 682-689.

74 Lee C, Corren J. Budesonide/formoterol in the treatment of asthma. Expert Rev Respir Med 2008; 2: 551-564.

75 Papi A, Paggiaro P, Nicolini G, et al. Beclomethasone/formoterol vs fluticasone/salmeterol inhaled combination in moderate to severe asthma. Allergy 2007; 62: 1182-1188.

76 Israel E, Roche N, Martin RJ, et al. Increased dose of inhaled corticosteroid versus add-on long-acting $\beta 2$-agonist for step-up therapy in asthma. Ann Am Thorac Soc 2015; 12: 798-806.

77 Bateman ED, Harrison TW, Quirce S, et al. Overall asthma control achieved with budesonide/formoterol maintenance and reliever therapy for patients on different treatment steps. Respir Res 2011; 12: 38.

78 Bateman ED, Buhl R, O'Byrne PM, et al. Development and validation of a novel risk score for asthma exacerbations: the risk score for exacerbations. J Allergy Clin Immunol 2015; 135: 1457-1464.

79 Eurostat. Statistics Explained. http://epp.eurostat.ec.europa.eu/statistics_explained/index

80 Kauppi P, Peura S, Salimäki J, et al. Reduced severity and improved control of self-reported asthma in Finland during 2001-2010. Asia Pac Allergy 2015; 5: 32-39.

81 Rytilä P, Ghaly L, Varghese S, et al. Treatment with inhaled steroids in patients with symptoms suggestive of asthma but with normal lung function. Eur Respir J 2008; 32: 989-996. 